\title{
ARCHAEOBOTANICAL REMAINS FROM THE MEDIEVAL TOWN OF BRANIČEVO (SERBIA)
}

\author{
Ana Smuk \\ Novi Sad \\ e-mail: ana.smuk5@gmail.com | Original scientific paper \\ Received: 1. 5. 2021. UDC: 902.2:633.1(497.11)"2007/..." \\ Accepted: 9. 6. 2021. 56:581"653"(497.11)
}

\begin{abstract}
Archaeobotanical investigations of medieval sites in the Balkans are still not being undertaken often enough, and this study represents a small insight into the economic activity related to food consumption of one house in the medieval town of Braničevo. Three archaeobotanical samples from House 4 in Mali Grad - the site of Todića Crkva in the town of Braničevo were collected during excavation campaigns in 2008 and 2011. The material was analysed and, as a result, showed a clean sample structure containing 333 findings of broad bean (Vicia faba), 2 seeds of pea (Pisum sativum), and 37 fruits of Mongolian cherry (Prunus fruticosa). Only a few cereals were present in the assemblage: one seed of rye (Secale cereale), two possible findings of millet (cf. Panicum miliaceum), and two probable seeds of barley (cf. Hordeum vulgare). Archaeobotanical findings from Braničevo are raising new questions in investigations of the site's economy and represent a part of the data collection process that will hopefully continue to grow when it comes to archaeobotanical investigations of the medieval sites in the Balkans.
\end{abstract}

Keywords: archaeobotany, Middle Ages, plant remains, faba bean (Vicia faba), Mongolian cherry (Prunus fruticosa), Braničevo

\section{Introduction: Medieval town of Braničevo}

The medieval fortification of Braničevo is located in eastern Serbia, around $20 \mathrm{~km}$ from Požarevac, in the village of Kostolac (Fig. 1), built near the Roman city of Viminacium. The urban centre of the site consisted of two fortified units called Mali Grad and Veliki Grad, situated on a natural elevation located at the left bank of the Mlava river. The sites of Rudine and Svetinja, as suburbs of the town of Braničevo, are located further down the two structures, on the right bank of the Mlava river (Fig. 2). Mali Grad, situated along a branch of the Danube (Dunavac) and the Mlava river, was protecting the passage of the Danube from the north and east. Hence, it is no surprise that this place, with such a position, has been inhabited since the fourth millennium $\mathrm{BC}$, a period called the Eneolithic (Поповић, Иванишевић 1988, 125; Спасић-Ђурић 2016, 109; D’Amato, Spasić-Đurić 2018, 29; Spasić-Đurić, Jovanović 2018, 151). 


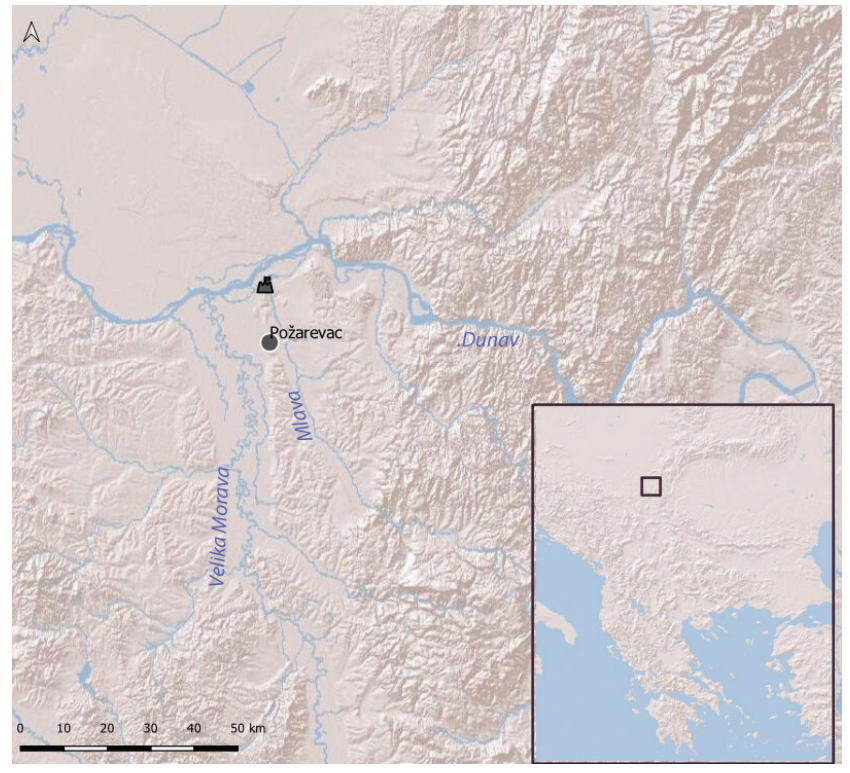

Fig. 1. The position of the site of Braničevo (Map by I. Kajtez and A. Smuk)

Сл. 1. Позиција локалитета Браничево (мапа И. Кајтез и А. Смук)

Braničevo is located in the zone of temperate continental climate with warmer and drier summers in the valleys of the Danube and Morava (Mrvić et al. 2011, 20). The Medieval Warm Period or Medieval Climatic Optimum, which encompassed the whole of Europe, begun around the $9^{\text {th }}$ century and lasted until the beginning of the $15^{\text {th }}$ century (Hughes, Diaz 1994, 109), with the warmest episodes occurring during the $12^{\text {th }}$ and the $13^{\text {th }}$ century. This warm epoch was followed by a climatic period known as the Little Ice Age, which took place in the $15^{\text {th }}$ century and lasted until the end of the $19^{\text {th }}$ century (Милићевић 2010, 662). The question that imposes itself is how big an influence the climate had when it came to decisions about what would be grown during the Middle Ages. That is one more reason why we need to build archaeobotanical data sets and collect more material from the medieval sites in the region, to be able to discuss questions like this.

Braničevo was mentioned in historical sources during the $11^{\text {th }}$ and $12^{\text {th }}$ century through notes of historians John Kinnamos and Nicetas Choniates describing the Byzantine-Bulgarian conflict in the area (Византијски извори за историју народа Југославије IV, 1971, 7-8, 117), but mainly without further notes about the appearance or the proportions of the fortress itself(Поповић, Иванишевић 1988, 125). Braničevo became an episcopal centre in the second decade of the $11^{\text {th }}$ century (under Basil II), getting jurisdiction over many places along the Danube and the Velika Morava rivers (Komatina 2012, 51). 


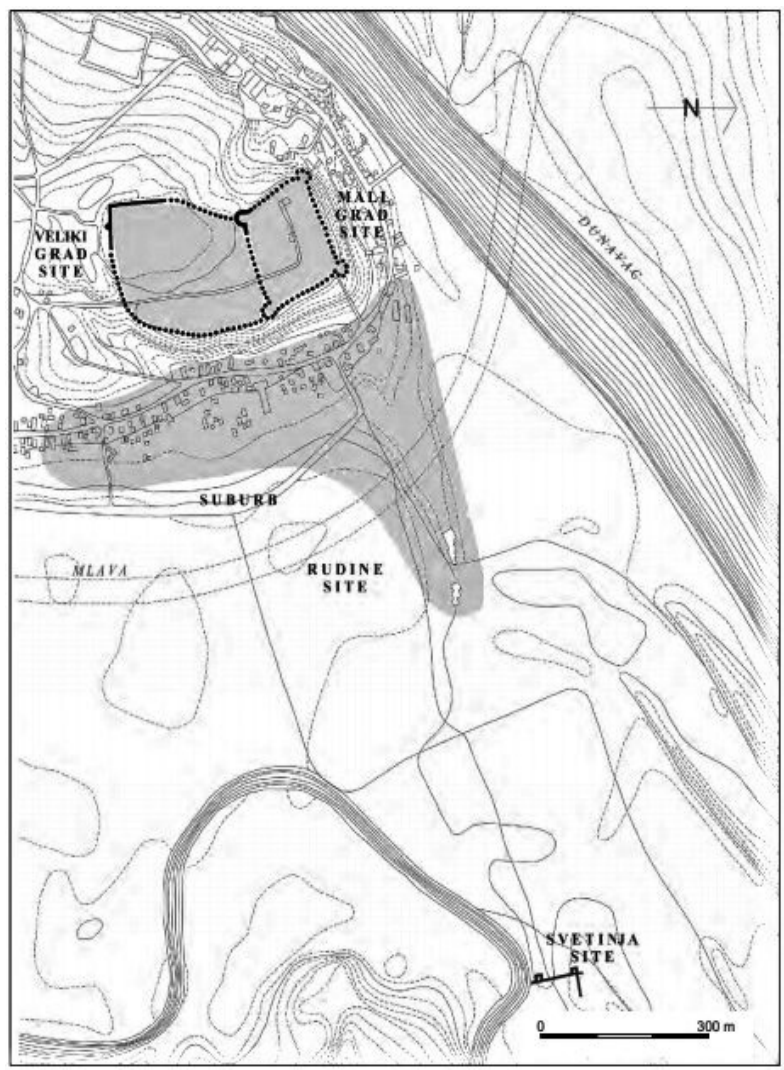

Fig. 2. Situation plan of the Medieval city of Braničevo (according to Поповић, Иванишевић 1988, 129, Fig. 2)

Сл. 2. Ситуациони план средњовековног града Браничево (према Поповић, Иванишевић 1988, 129, сл. 2)

During the $12^{\text {th }}$ century, this fortress was the center of almost constant conflicts between the Byzantine Empire and Hungary, as Braničevo was, along with Belgrade, the most important stronghold on the Byzantine-Hungarian border. After the collapse of Byzantine power in this area during the early $13^{\text {th }}$ century, conflicts were continued by Hungary and Bulgaria, until the end of the century, when Braničevo became a part of the Serbian Kingdom (Византијски извори IV, 17-22; Динић 1978, 93-97).

The site was excavated in several campaigns during the $20^{\text {th }}$ century, the result of which was, a topographic reconstruction of the town and primary stratigraphy of Mali and Veliki Grad (Поповић, Иванишевић 1988, 127-133; D'Amato, Spasić-Đurić 2018, 30). Further excavations have been conducted since 2007, at the site of Mali Grad - Todića Crkva, with the surface of $720 \mathrm{~m}^{2}$ having been in- 


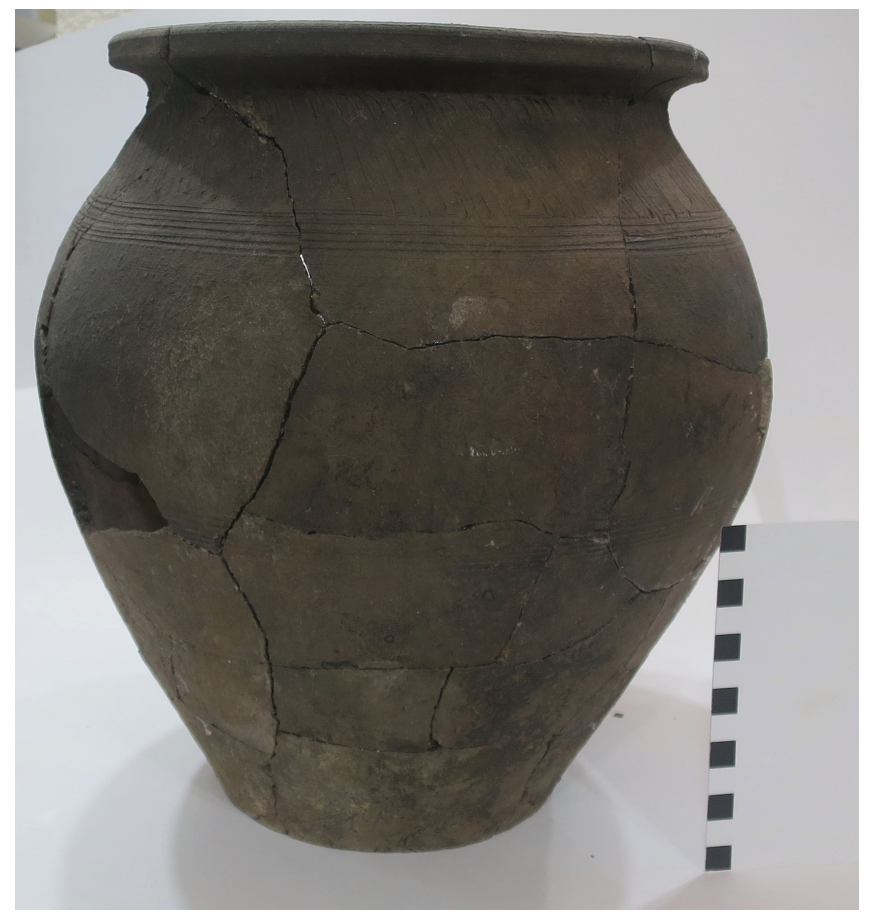

Fig. 3. Ceramic vessel from the north-western part of House 4, which probably contained findings of broad bean - Vicia faba. (Photo by D. Spasić-Đurić)

Сл. 3. Керамичка посуда из северозападног дела куће 4, која је вероватно садржала налазе боба - Vicia faba (фотографија Д. Спасић-Ђурић)

vestigated, mainly on the western part of the site. Besides Hallstatt ( $8^{\text {th }}-4^{\text {th }}$ century BC) and Late La Tène - Early Roman ( $2^{\text {nd }}$ century BC- $2^{\text {nd }}$ century AD) cultural horizon, a medieval period horizon was also identified (Спасић-Ђурић 2015, 19-21; Спасић-Ђурић 2016, 109), and will be further considered in this paper.

The most developed and the best-researched phase of the town of Braničevo belongs to the $12^{\text {th }}$ century. On the western side of the site, a structure house (labelled House 4) was discovered and excavated in 2007-2011. The structure, with around 136.5-150 $\mathrm{m}^{2}$, was dated by the findings of coins of Roman Emperors John II (AD 1118-1143) and Manuel I Komnenos (AD 1143-1180), found on the floor of the house. It was a heavily burned house, but on the basis of the charred wooden structure and preserved floor, some basic architectural features could be determined. A loose, burned layer above the house floor maintained a lot of artefacts, 72 in situ ceramic vessels and a lot of pottery fragments, many among them luxuriously made (Спасић-Ђурић 2016, 110 -115; D’Amato, Spasić-Đurić 2018, 33). 


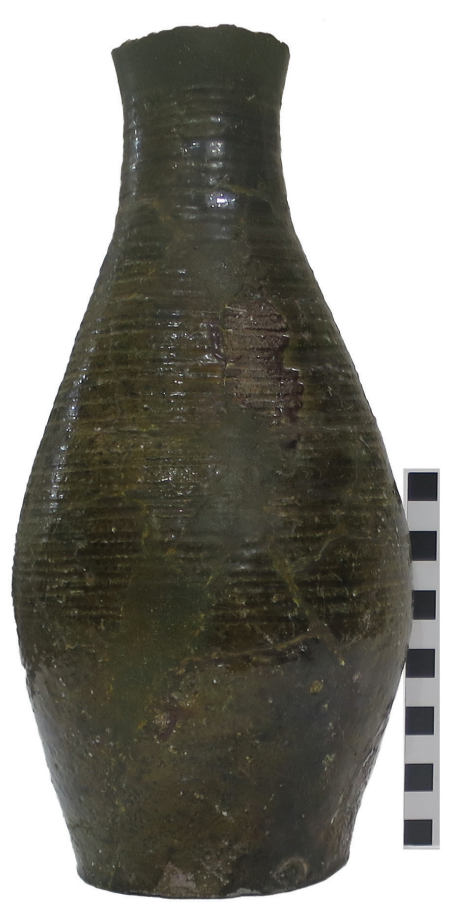

Fig. 4. Glazed ceramic vessel from the southeastern part of House 4, which contained findings of Mongolian cherry - Prunus fruti$\cos a$ (Photo by D. Spasić-Đurić)

Сл. 4. Глеђосана керамичка посуда из југоисточног дела куће 4, која је садржала налазе степске вишње - Prunus fruticosa (фотографија Д. Спасић-Ђурић)

\section{Material and Methods}

In the north-western part of House 4, during the excavation campaign of 2008, in a thin layer of burned soil, ash, and collapsed walls, just above the floor, a lot of ceramic vessels and pottery fragments were found, together with a certain amount of animal bone fragments. The cleaning of a burned ceramic vessel lying on the ground in pieces (Fig. 3) uncovered a certain amount of dispersed archaeobotanical findings around and beneath the pottery fragments. Soil sample that contained archaeobotanical remains has been sampled for further archaeobotanical analysis, later labelled as Sample 1. Considering the archaeological context of the first sample, it is suggested that it was probably part of the content of the ceramic vessel presented in Fig. 3. The second sample came from the same part of House 4 as the first one; few cereal grains were spotted near bird bones and were collected for identification.

The south-eastern part of House 4 was excavated in 2011, having a similar situation as in the north-western part of the structure - destruction layers of burned soil, bricks, and debris with lots of pottery fragments. In this part of the house, pieces of a burned, glazed ceramic bottle were found. The bottle was broken and slightly deformed from the burning, but successfully reconstructed (Fig. 4). The object was made on fast wheel, having a long neck, flat bottom, and hori- 
zontal lines on the upper part of the body. The neck is partly missing, as well as the rim of the bottle. Archaeobotanical findings were registered in the soil inside of it. The whole content of the glazed bottle (later labelled as Sample 3) was collected without sieving or flotation.

Due to the visibility of the archaeobotanical material, soil samples have been collected from the site and then sent to the National Museum of Požarevac, without sieving or flotation. They were loaned to the author of this paper in 2020 for further analysis and identification.

All plant remains from Braničevo were preserved as a product of the charring process. Charred or carbonized remains are the most common type of archaeobotanical findings on archaeological sites (Evans, O' Connor 2001, 137138), especially in South-Eastern and Central Europe. In the case of House 4, it is reasonable to suggest that this charring was the consequence of the severe burning that the house suffered. The data set from Braničevo comes from three samples: two from the campaign of 2008 (north-western part of the structure was excavated) and one from the campaign of 2011 (south-eastern area of the house was investigated).

Archaeobotanical samples were divided through 4 sieves (sieve meshes were $2 \mathrm{~mm}, 1 \mathrm{~mm}, 0.6 \mathrm{~mm}$, and $0.3 \mathrm{~mm}$ ), with a full bottom at the end, which made the division of the material and further sorting process easier. Part of the sample - dust that goes through the smallest diameter sieve - was dismissed. During the sorting process, the archaeobotanical material was extracted from the rest of the sample, consisting mainly of soil and dirt. The process of identification was made with a stereo microscope with a $7-45 \mathrm{x}$ magnification and with the help of seed identification manuals, atlases (Beijerinck 1976; Cappers et al. 2012), and digital collections available online ${ }^{1}$. The nomenclature of scientific plant names for cultivated plants follows Zohary and Hopf (2000).

Eight small pieces of wood charcoal were noted but not identified. Seed remains were counted when preserved with the embryo end in the case of cereal grains, and when they were whole or at least having one half (in this case, two halves would be counted as one) in the case of the pulse seeds. If the part of a cereal grain would not have an embryo end and if there was less than half of the pulse seed, it was not counted. Fruits were counted as one when more than half of the fruit stone was preserved.

When it comes to the identification criteria regarding the Mongolian cherry, it was clear from the beginning that what was found in the vessel was belonging to the Prunus genus, but it was hard to determine the material on the

\footnotetext{
${ }^{1}$ https://www.plantatlas.eu// http://luirig.altervista.org/ https://plants.sc.egov.usda.gov/java/
} 
species level. As is often the case with the Mongolian cherry, the fruits' flesh was completely fused to the stone, which made the identification process difficult. It was impossible to see the outer surface of the stone. Fruits were probably already dried when placed into the pot, or they were dried in the pot, as the material was half-charred and the fruits were very well preserved. The inside surface of the fruit stone, its shape and size, the appearance of the seed and the whole fruit, and comparison of the material with features of other Prunus species, lead to the conclusion that what was found in Braničevo is ground cherry (Prunus fruticosa).

\section{Results}

House 4 provided us with the archaeobotanical data set consisting of domesticated cereals and pulses, and findings of a fruit species. Table 1 shows the species found on-site in three samples. Cereal species found in Braničevo are rye (Secale cereale), and probably millet (Panicum miliaceum), and barley (Hordeum vulgare). Millet and barley were very poorly preserved (probably due to the high temperatures during the fire when the house burned down) and could be identified at the "cf" (possibly millet/barley) level. Broad bean (Vicia faba) was found in the highest amounts compared to the rest of the species, 333 seeds accompanied with two seeds of pea (Pisum sativum). Broad bean, pea, and possibly barley were found in Sample 1, whereas rye and possibly millet were part of Sample 2.

The most interesting finding comes from a glazed luxury vessel -37 fruits of Mongolian cherry (Prunus fruticosa), this being the first time it was found in a medieval context on the Balkans. Both samples that came from the vessels were cleaned of weeds, probably by sieving, which, with the archaeological context (ceramic vessels that contained plant remains), implies that they were stored before the house burned down and collapsed. Fig. 5 shows the representation of each category of finds from House 4 in Braničevo.

\section{Discussion}

The archaeobotanical material from Braničevo gives us essential information about everyday activities on-site and about the plants cultivated and collected that were kept indoors for further processing and consumption. The presence of cereals and pulses inside House 4 suggests that these products may have been grown and consumed by the residents of the house. The finds of Mongolian cherry indicate plant use that included species more diverse than cereals and pulses. The apparent storage of cherries in a piece of fine ware tells us about their possible specific purpose in this house. 


\begin{tabular}{|l|r|r|r|}
\hline \multicolumn{2}{|c}{ Sample 1 } & \multicolumn{1}{c|}{ Sample 2 } & Sample 3 \\
\hline Cont ext & Ceramic pot & Soil near bird bones & Glazed bottle \\
\hline Cer eals & & & \\
\hline Secale cereale & & 1 & \\
\hline cf. Panicum miliaceum & & 2 & \\
\hline cf. Hordeum vulgare & 2 & & \\
\hline Cerealia indeterminata & & & \\
\hline Legumes & & & \\
\hline Vicia faba & 333 & & \\
\hline Pisum sativum & 2 & & \\
\hline Leg.sat.indet. & 1 & & \\
\hline Fruit species & & & 37 \\
\hline Prumus fruticosa & & & 38 \\
\hline Total & $\mathbf{3 3 8}$ & & \\
\hline
\end{tabular}

Tab. 3. List of the plant species found in House 4 at the site of Braničevo

Таб. 3. Листа биљних врста нађених на простору куће 4 на Браничеву

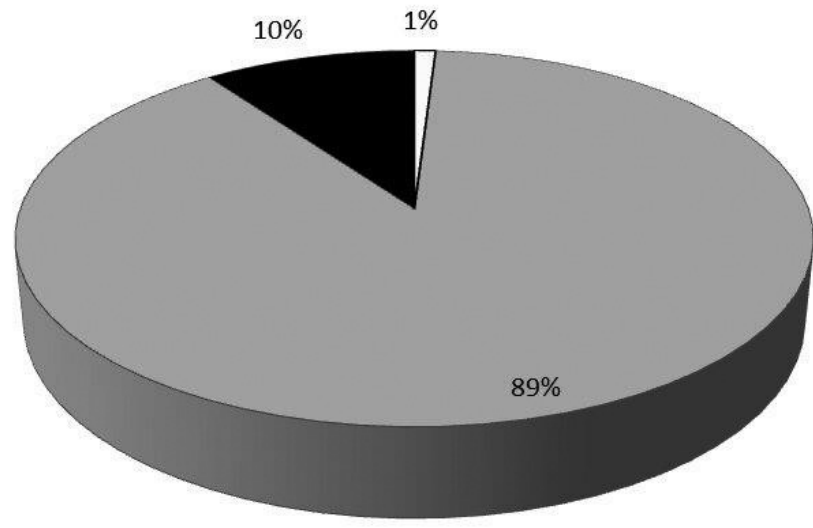

口Cereals

$\square$ Legumes

Eruits

Fig. 5. Representation (in percentages) of different plant categories at the site of Braničevo Сл. 5. Процентуална заступљеност различитих биљних категорија на Браничеву 
Rye (Secale cereale)

Although based on a single find of the grain, rye was confirmed on the site of Braničevo. Some other medieval sites in the region provided traces of rye, among other cereals. It was found on the $12^{\text {th }} / 13^{\text {th }}$ century fortress of Ras (Боројевић 2002; Borojević 2005) and the $14^{\text {th }}-16^{\text {th }}$ century fortress of Koznik (Medovic 2016), as well as in the $13^{\text {th }} / 14^{\text {th }}$ century context of the monastery of Studenica (Филиповић, Бикић 2015), all located in Serbia; in Croatian Early Medieval contexts, rye was found on the $8^{\text {th }} 9^{\text {th }}$ century site of Virovitica Kiškorija South (Šoštarić 2015) and on the $8^{\text {th }} / 9^{\text {th }}$ century Avar cemetery in Nuštar (Rapan Papeša, Kenez, Peto 2015). This cereal is present in larger numbers in Hungary, as hundreds of grains were collected from the $7^{\text {th }}-9^{\text {th }}$ century settlement of Fonyód-Bélatelep (Gyulai et al. 1992), the $12^{\text {th }} / 13^{\text {th }}$ century settlement of Hajdúböszörmény (Gyulai et al. 2016; Gyulai et al. 2017), and the Late Medieval $\left(13^{\text {th }}-16^{\text {th }}\right.$ century) town of Vác (Gyulai 1995). One grain found in House 4 is not revealing much, if it was contamination in some other crop species, or it might have been cultivated, is something only further investigation could answer to.

Rye never had the same level of importance in South-Eastern Europe as it had in Central and Northern Europe (Kroll 1991, 167-168; Behre 1992, 141; Šoštarić, Šegota 2010a, 249), being a flexible species for cultivation as it grows very well in poor soils and under a broad spectre of climatic conditions (Gyulai 2014a, 25). This cereal could have been used for the human diet (for making dark bread, for example), or for animals as fodder (Medović 2008, 155; Grikpedis, Motuzaite Matuzeviciute 2016, 601; Kim et al. 2017, 551). Rye was mentioned in Serbian history books as the cereal grown either alone in the field or as a mixture with Triticum aestivum - bread wheat (Благојевић 1973, 101; Јиречек 1978, 168; Popović et al. 2016, 137).

\section{Millet (Panicum miliaceum)}

Millet has had a role in the human diet in Europe since the Bronze Age (Filipović et al. 2020). It has a relatively short growing season (from 60 to 90 days) and thrives in a warm climate and with lots of light. Millet is usually sown in spring, but sometimes it can have a second sowing season in summer (Боројевић $2002,198)$. It could have been used for making bread, porridge, and beer. It could also have served as yeast or a base for bread making from other cereals (Plinius NH, XVIII, pp. 102-104).

Millet remains present through all phases of the medieval period on archaeological sites in the Balkans and Pannonian Basin. In Serbia, it was found in both of the archaeobotanically investigated medieval fortresses, in significant 
amount in $12^{\text {th }} / 13^{\text {th }}$ century Ras (Боројевић 2002; Borojević 2005), and Koznik $\left(14^{\text {th }}-16^{\text {th }}\right.$ century) (Medović 2016). It was the primary cereal from the $8^{\text {th }}-9^{\text {th }}$ century Avar cemetery in Nuštar (Rapan Papeša, Kenez, Peto 2015), and it has also been found in several medieval layers in Croatia $\left(7^{\text {th }} / 8^{\text {th }}\right.$ and $10^{\text {th }}-14^{\text {th }}$ century) at the settlements in the region of Torčec near Koprivnica (Šoštarić 2004; Šoštarić, Šegota 2010b), at the $8^{\text {th }} / 9^{\text {th }}$ century site of Virovitica Kiškorija South (Šoštarić 2015 ) and the $12^{\text {th }}-16^{\text {th }}$ century Vrbovac in Klenovac Humski (Šoštarić, Šegota 2010a). In Hungary, it appeared in significant amounts at the Early Medieval ( $8^{\text {th }} 9^{\text {th }}$ century) lakeshore settlement near the lake of Balaton (Gyulai et al. 1992), in the $12^{\text {th }} / 13^{\text {th }}$ century settlement of Hajdúböszörmény (Gyulai et al. 2016; Gyulai et al. 2017), and in $15^{\text {th }}$ century Budapest (Lagler et al. 2005). Finally, after the arrival of the Ottomans $\left(14^{\text {th }}-16^{\text {th }}\right.$ century) in this part of Europe, millet lost its significance, as maize (Zea mays) came to this region and replaced millet during the $17^{\text {th }}$ century (Medović 2015).

Two seeds of what seems as millet are not enough for us to conclude anything regarding agricultural activities that might include millet in the town of Braničevo. The overview of its presence at other medieval sites in the region, though, together with the works of historians stating that millet was often cultivated in the fields of medieval Serbia and was one of the species that people traded with (Dinić-Knežević 1967, 82; Благојевић 1973, 101; Јиречек 1978, 168; Храбак 1994, 48), gives us an idea of its significance in the region during the medieval period and therefore keeps the possibility of its cultivation in Braničevo open.

\section{Barley (Hordeum vulgare)}

Similarly to the case of millet, two possible grains of barley were found in House 4. Barley can be sown both in autumn and spring, and it thrives under various climatic conditions. Historical sources mention barley being sown together with bread wheat (Благојевић 2004, 82), like in the case of the mixing of wheat and rye. It could have been used for human and animal diet and as a base for beer-making (Ozanić Roguljić 2015, 328).

Barley has been collected from all three medieval sites in Serbia that have been archaeobotanically investigated and published - Ras, Studenica and Kozik (Боројевић 2002; Borojević 2005; Филиповић, Бикић 2015; Medović 2016). It was also present in three publications related to the Croatian territory - Vrbovac in Klenovac Humski site (Šoštarić, Šegota 2010a), on the medieval settlements in the region of Torčec near Koprivnica (Šoštarić 2004; Šoštarić, Šegota 2010b), and on the Avar cemetery in Nuštar (Rapan Papeša, Kenez, Peto 2015). In Hungary, bar- 


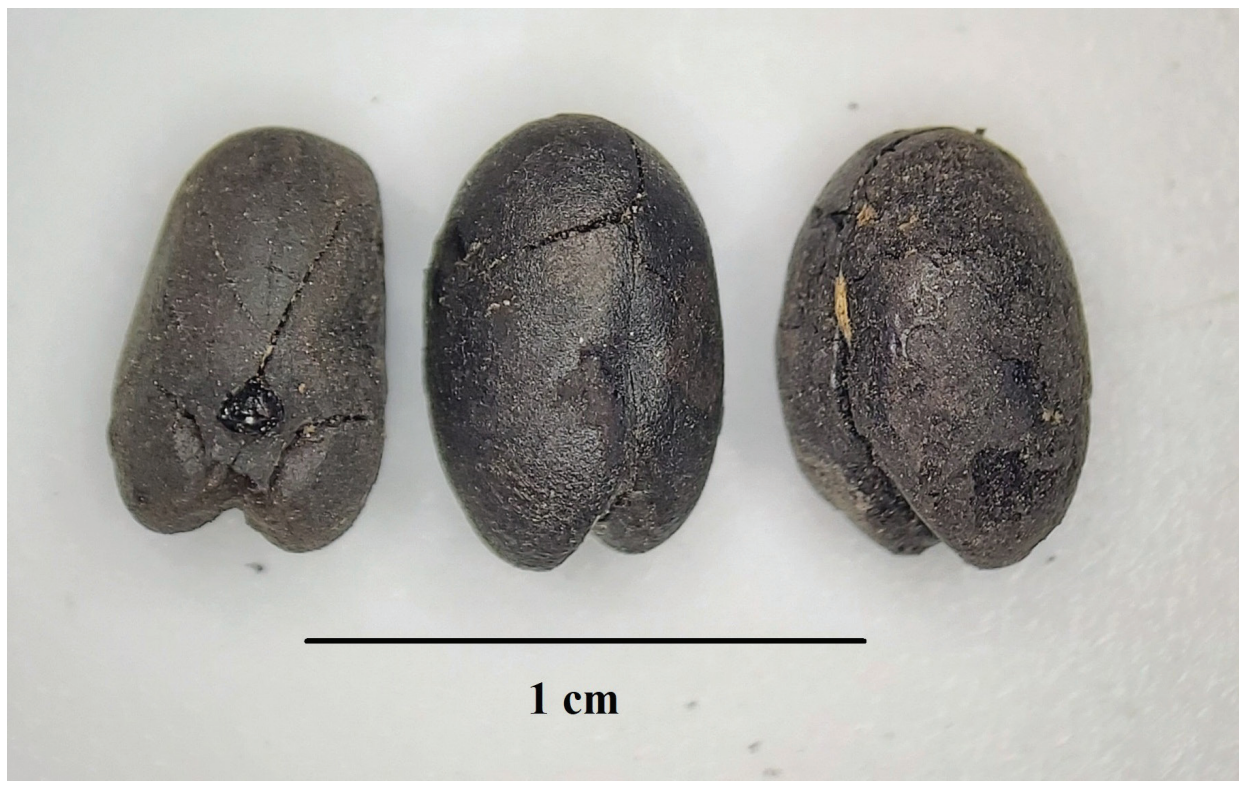

Fig. 6. Archaeobotanical findings of broad bean (Vicia faba) from Braničevo (Photo by A. Smuk)

Сл. 6. Археоботанички налази боба (Vicia faba) са Браничева (фотографија А. Смук)

ley was found in Fonyód-Bélatelep (Gyulai et al. 1992), Hajdúböszörmény (Gyulai et al. 2016; Gyulai et al. 2017) and the medieval town of Vác (Gyulai 1995).

As our two possible findings of barley were discovered among hundreds of broad bean seeds, it is unclear if the barley came from the same ceramic vessel as broad bean did (and therefore made its way into the vessel accidentally with the pulses when they got stored), or it was already on the floor at the moment when the vessel with legumes collapsed. Regarding its possible significance in Braničevo, only further investigations and more finds of this species would enable us to discuss the role that barley might have had in this town during the medieval period.

\section{Broad bean (Vicia faba)}

Pulses are an important source of proteins, and along with cereals, they make up the most essential plant food base (Vasić et al. 2006, 1-2). Archaeological finds of pulses, especially in high amounts, indicate that they were cultivated, but that cannot help us make the distinction between those used for humans and those used for animal consumption (Valamoti et al. 2011, 382). In the case of Braničevo, the archaeological context speaks for itself. Pulses (Fig. 6) were collected, cleaned, and deposited in a pot, ready for further preparation. 
One seed of faba bean was found in Vrbovac at the site of Klenovac Humski $\left(12^{\text {th }}-16^{\text {th }}\right.$ century) in Croatia (Šoštarić, Šegota 2010a) and nowhere else when looking at other contemporaneous sites in the region that were archaeobotanically investigated, published, and included in this paper. Therefore, this finding from Braničevo represents an important addition to the data set of plant remains used in the Balkans during the Middle Ages in terms of pulse use. Here, we have an archaeobotanical confirmation of what we have seen in historical sources in the country, that faba bean did make a part of the medieval diet. Written sources from medieval Serbia inform us that broad bean had its role in everyday diet, as being very rich in proteins, thus it could have served as a substitute for meat. This pulse can grow well under colder climatic conditions too, so it was sown across the Balkan Peninsula in the medieval period (Благојевић 1973, 104). During this time, it was also believed that faba bean juice had medicinal properties and was good for the health (Новаковић 1904, 592). It was also used in meals as puree, served in soups, or dry, in salads (Храбак 1994, 43). In crop husbandry regimes, beans were cultivated as both garden and field crops. Cultivation of the faba bean was also improving soil fertility (Treasure, Church 2017, 113).

Similarly to the case of millet, faba bean was losing its significance in later periods, when common bean (Phaseolus vulgaris) was introduced into this part of Europe in the $17^{\text {th }} / 18^{\text {th }}$ century (Zeven 1997, p. 319). Today, faba bean is being used in diets sporadically, such as in Orthodox monasteries in the territory of Serbia. Broad bean is a multi-purpose crop that can be used for both human consumption and as fodder for animals (Mihailović et al. 2010, 27-28).

\section{Pea (Pisum sativum)}

Pea was also one of the pulses present during the medieval period in this part of Europe, as it was found at the medieval site of Hajdúböszörmény (Gyulai et al. 2016; Gyulai et al. 2017) and the medieval town of Vác (Gyulai 1995). Pea was used in both human and animal diet. As it is nitrogen-fixing, it was often used in crop rotations to help fix nitrogen in the soil (Kosterin et al. 2020, 61).

The findings from Braničevo cannot tell us too much about the possible cultivation of this pulse. Just two seeds have been found among the 333 seeds of broad bean, so it cannot be said if this finding of pea was contamination in the field or in the pot. If it was cultivated like broad bean, there is the possibility that it got mixed in one stage of the processing on the site or later when preparing the food for storage. Considering the archaeobotanical findings of pea from other medieval sites (Gyulai 1995; Gyulai et al. 2016; Gyulai et al. 2017) and the information provided by written sources (Благојевић 1973, 104), there is a possibility that pea was cultivated in medieval Braničevo. 
Mongolian cherry (Prunus fruticosa)

Mongolian or ground (dwarf) cherry is a member of the family Rosaceae and belongs to the Prunus genus. Prunus comprehends around 200 species, mostly deciduous or evergreen trees and shrubs (Barać 2016, 3). Mongolian cherry is native in and widespread over most of Central and Eastern Europe, Balkan Peninsula, Apennine Peninsula, Caucasus, western Siberia, and Central and Northern Asia (Burger et al. 2011, 2; Yang et al. 2020, 3606). It grows mainly in the flatlands with dry steppe vegetation, on open hills, gorges, and edges of river valleys (Wojcicki, Marhold 1993, 15; Hrotko et al. 2020, 489-490). In Serbia, it grows within shrubby steppe vegetation along the edges of forests of thermophilic character and on sunny slopes. It has the form of a hedge or a small shrub, especially in abandoned vineyards. It is 0.2-2 $\mathrm{m}$ high, with oval/elliptical leaves and white flowers. It blooms in April/May and fully develops in July (Barać 2016, 4).

The fruit has a red colour (from light to dark red - sometimes almost black), and can have $7-10 \mathrm{~mm}$ in diameter. The taste of the fruit is sour-sweet, occasionally astringent. The fruit stone is small and has an oval/ellipsoidal shape, tapered towards the ends. The fruit flesh adheres completely to the fruit stone. Ground cherry is one of the progenitors of cultivated sour cherry (Prunus cerasus). It is resistant to winter frosts and drought, matures early, and produces abundant roots (Dzhangaliev et al. 2003, 327; Milatović, Nikolić 2011, 40; Barać 2016, 4).

Findings of dwarf cherry (Fig. 7) from glazed ceramic vessel collected in the south-eastern part of House 4 on Braničevo represent the first findings of this species from a medieval context in the Balkans region.

The species is native in this part of Serbia, so it would be reasonable to suggest that material from House 4 was collected in the site's surroundings and used by the residents of the house. Still, the question that naturally imposes itself is what the use of this species was on the site. It was collected and preserved in a high quality, luxuriously made ceramic vessel, which gives more value to the archaeobotanical material itself. Some of the uses and purposes of the dwarf cherry found in such a context and condition could be tea making, as an ethnobotanical study in the region showed other species of Prunus genus such as sweet cherry (Prunus avium), sour cherry (Prunus cerasus) and blackthorn (Prunus spinosa) were used in tea making mostly for health reasons (Bajrami et al. 2016, 467 ) or consumption of dried fruit. It could be used in baking and making cake; Mongolian cherry could also be used for medicinal purposes, as an astringent for coughs, colds, and gout. It is also good for honey, making jams and jellies (Dzhangaliev et al. 2003, 327). 


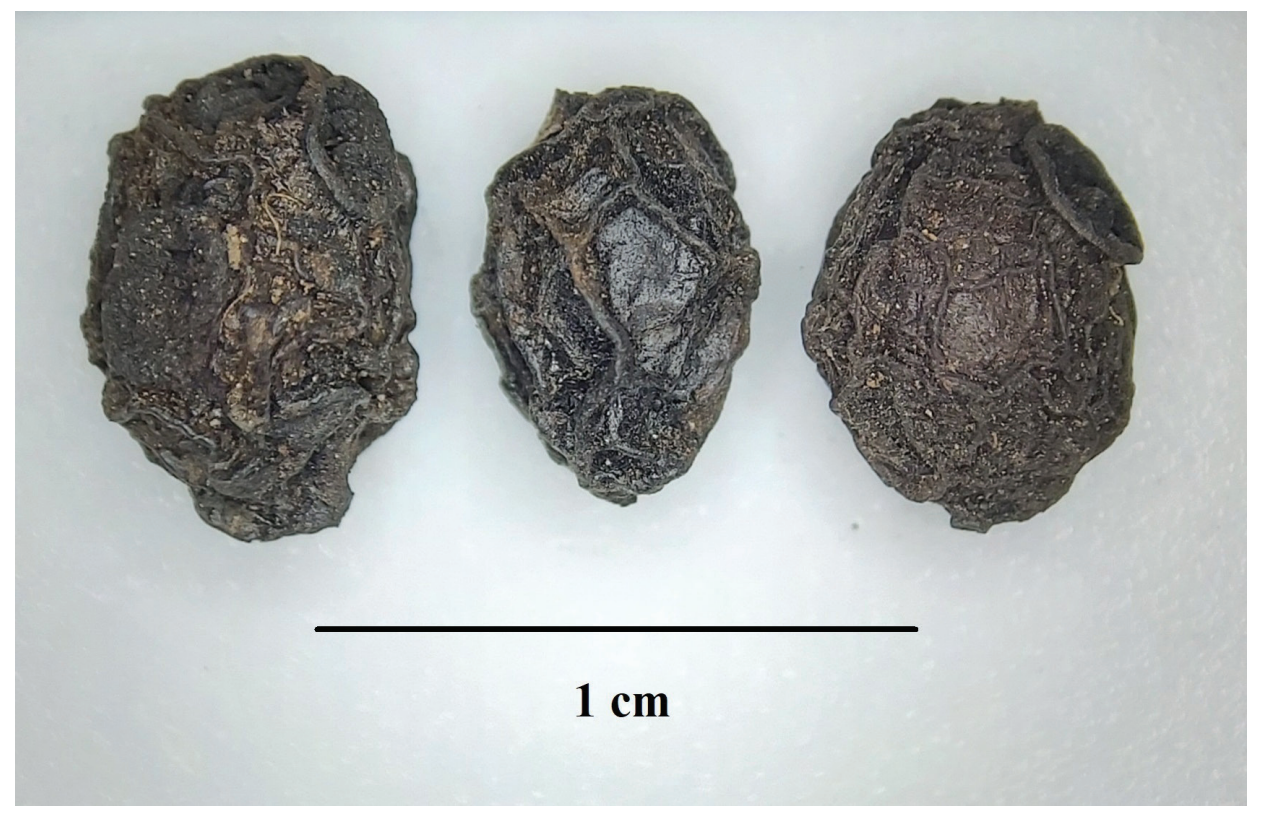

Fig. 7. Archaeobotanical findings of Mongolian cherry (Prunus fruticosa) from Braničevo (Photo by A. Smuk)

\section{Сл. 7. Археоботанички налази степске вишње (Prunus fruticosa) са Браничева (фотографија А. Смук)}

Plant use within House 4 in Braničevo

The archaeobotanical material from Braničevo is showing us the presence of cereal species (rye, millet, and barley) we had the opportunity to note on several other medieval sites in Serbia, Croatia, and Hungary that were archaeobotanically analysed and published - Ras, Studenica, Koznik, Virovitica Kiškorija South, Vrbovac in Klenovac Humski, Torčec near Koprivnica, Nuštar, Budapest, Fonyód-Bélatelep, Hajdúböszörmény and Vác (Gyulai et al. 1992; Gyulai 1995; Боројевић 2002; Šoštarić 2004; Borojević 2005; Lagler et al. 2005; Šoštarić, Šegota 2010a; 2010b; Šoštarić 2015; Филиповић, Бикић 2015; Medović 2016; Gyulai et al. 2016; Gyulai et al. 2017).

The presence of rye and probably millet and barley, with written testimonies and archaeobotanical results from contemporaneous sites in the region, brings us to the assumption that these species could have been part of the everyday diet in Braničevo. Especially when we look at the Ottoman census book (defter) of 1476, which notes that residents of the province of Braničevo were obligated to pay taxes for agricultural goods that were cultivated in the area. The species mentioned through this type of source are millet, barley, wheat, oat, lentil, 
flax, and fruits and vegetables (Stojaković 1987, 81-2). This information tells us that species found in the medieval context of House 4 were cultivated during the later Ottoman period. There is not enough material and evidence for further analysis, which at the moment prevents us from forming conclusions as to which cereals were cultivated and consumed in the $12^{\text {th }}$ century Braničevo.

The unusual thing that was brought to the archaeobotanical data set of the medieval period in this region is the appearance of Mongolian cherry. The presence of broad bean in House 4 at Braničevo suggests its importance in the diet of the residents. These finds also provide information on the way of storing legumes - probably on shelves in the north-western part of House 4. The position of ceramic vessels, which were broken and scattered in the area of $5 \mathrm{~m}^{2}$, indicates that they had a place on higher shelves, unlike those which were broken but preserved in situ (Спасић-Ђурић 2016, 112). This can contribute to the future analysis regarding the use of space within this structure, along with the related archaeological and archaeozoological results. The glazed vessel containing dwarf cherries was found on the opposite side of the house - in its south-eastern part. It could be assumed that coarse ware was used for the storage of pulses and in the part of the house that served for storing and keeping the food safe and dry. The Mongolian cherries might have been kept in fine ware and areas used for food or drink preparation, or food serving. The findings of ground cherry also indicate that the food economy of House 4 was not purely based on cereals and pulses, but that wild plants were also in use and that they were available in their surroundings.

\section{Conclusion}

House 4 in Mali Grad - the site of Todića Crkva has given some insights through archaeological investigations and findings into the administrative, trading, military and political aspects of life in Braničevo during the $12^{\text {th }}$ century (СпасићЂурић 2016, 115). Archaeobotanical investigations have now added to this previous research, by providing important information on everyday plant-related activities in medieval Braničevo. These results also provide us with a rare insight into a small part of the food economy of the $12^{\text {th }}$ century in Serbia, which is a period that hasn't been investigated much in the archaeobotanical sense. In that manner, it would be of great value to see where future archaeobotanical analyses would take us regarding this site.

\section{Acknowledgements}

I would like to express my deepest gratitude to Dragana Spasić-Đurić, archaeologist and curator from the National Museum of Požarevac and the director of the investigations of Braničevo since 2008, for lending me the archaeobo- 
tanical material to analyse, for providing me with all the data and information necessary for this paper, and for giving me invaluable support during the whole process of analysing and writing this paper.

I would also like to sincerely thank Aleksandar Medović, an archaeobotanist and curator in the Museum of Vojvodina, who helped with the identification of Mongolian cherry (Prunus fruticosa).

\section{REFERENCES}

Bajrami, A., Icka, P., Damo, R. 2016. An Ethnobotanical Study of Plants Used for Tea Making in Kosovo and Albania. International Conference on Sustainable Development in Skopje, Skoplje, EBSCO Publishing: 463-470.

Barać, G. 2016. Evaluacija genetičke i fenotipske varijabilnosti i analiza strukture populacije stepske višnje (Prunus fruticosa Pall.). Doktorska disertacija, Univerzitet u Novom Sadu.

Behre, K. 1992. The history of rye cultivation in Europe. Vegetation History and Archaeobotany 1:141-156.

Beijerinck, W. 1976. Zadenatlas der Nederlandsche Flora. Amsterdam: Backhuys \& Meesters.

Благојевић, М. 1973. Земљорадња у средњовековној Србији. Београд: Историјски институт.

Благојевић, М. 2004. Земљорадња у средњовековној Србији. Београд: Службени лист .

Боројевић, К. 2002. Анализа биљних остатака са тврђаве Рас (12. век и почетак 13. века). Старинар LII: 191-205.

Borojević, K. 2005. Nutrition and environment in medieval Serbia: charred cereal, weed and fruit remains from the fortress of Ras. Vegetation History and Archaeobotany 14: 453-464.

Burger, P., Terral, J., Ruas, M., Ivorra, S., Picq, S. 2011. Assessing past agrobiodiversity of Prunus avium L. (Rosaceae): a morphometric approach focused on the stones from the archaeological site Hôtel-Dieu (16th century, Tours, France). Vegetation History and Archaeobotany 20: 1-12.

Cappers, R., Bekker, R., Jans, J. 2012. Digitale Zadenatlas van Nederland. Groningen: Archaeological Studies 4.

D'Amato, R., Spasić-Đurić, D. 2018. The Phrygian helmet in Byzantium: archaeology and iconography in the light of recent finds from Braničevo. Acta Militaria Mediaevalia XIV: 29-67.

Dinić-Knežević, D. 1967. Trgovina žitom u Dubrovniku u XIV veku. Godišnjak Filozofskog fakulteta u Novom Sadu X: 1-53. 
Динић, М. 1978. Област централне Србије у средњем веку. Српске земље у средњем веку, ур. С. Ћирковић. Београд: Српска књижевна задруга: 55-112.

Dzhangaliev, A., Salova, T., Turekhanova, P. 2003. The Wild Fruit and Nut Plants of Kazakhstan. Horticultural Reviews, Volume 29: 305-372.

Evans, J., O'Connor, T. 2001. Environmental Archaeology. Sutton publishing.

Филиповић, Д., Бикић, В. 2015. Биљни остаци из манастира Студенице. Скуnштина и годишњи скуп САД, Пирот, 4-6. јун 2015. године. Програм, извештаји и апстракти. Пирот: 91.

Filipović, D., Meadows, J., Dal Corso, M., Kirleis, W., Alsleben, A., Akeret, Ö., Bittmann, F., Bosi, G., Ciută, B., Dreslerová, D., Effenberger, H., Gyulai, F., Heiss, A.G., Hellmund, M., Jahns, S., Jakobitsch, T., Kapcia, M., Klooß, S., Kohler-Schneider, M., Kroll, H., Makarowicz, P., Marinova, E., Märkle, T., Medović, A., Mercuri, A.M., Mueller-Bieniek, A., Nisbet, R., Pashkevich, G., Perego, R., Pokorný, P., Pospieszny, L., Przybyła, M., Reed, K., Rennwanz, J., Stika, H.-P., Stobbe, A., Tolar, T., Wasylikowa, K., Wiethold, J., Zerl, T. 2020. New AMS-14C dates track the arrival and spread of broomcorn millet cultivation and agricultural change in prehistoric Europe. Scientific Reports 10: 13698.

Grikpedis, M., Motuzaite-Matuzeviciute, G. 2016. The beginnings of rye (Secale cereale) cultivation in the East Baltics. Vegetation History and Archaeobotany 25: 601-610.

Gyulai, F. 1995. Plant exploitation and agriculture. Animals in the urban landscape in the wake of the Middle Ages: a case study from Vac, Hungary. Oxford: British Archaeological Reports.

Gyulai F. 2010. Archaeobotany in Hungary: seed, fruit, food and beverage remains in the Carpathian Basin from the Neolithic to the Late Middle Ages. Budapest: Archaeolingua. Gyulai F. 2014a. Archaeobotanical overview of rye (Secale cereale) in the Carpathianbasin from the beginning until the roman age. Columella - Journal of Agricultural and Environmental Sciences 1 (2): 25-36.

Gyulai F. 2014b. The history of Broomcorn millet (Panicum miliaceum) in the Carpathian-basin in the mirror of archaeobotanical remains from the roman age until late medieval age. Columella - Journal of Agricultural and Environmental Sciences 1: 39-49.

Gyulai F., Hertelendi E., Szabo I. 1992. Plant remains from the early medieval lakeshore settlement Fonyod-Bélatelep (Lake Balaton, Hungary) with especial emphasis on the history of fruit cultivation in Pannonia. Vegetation History and Archaeobotany 1: 177-144.

Gyulai, F., Szolnoki, L., Kenez, A., Peto, A. 2016. Economic history of the medieval Ishmaelite community of Hajduboszormeny $\left(12^{\text {th }}-13^{\text {th }}\right.$ centuries $)$ as reflected in the archaeobotanical record. Hungarian Archaeology e-journal: 1-8. http://files.archaeolingua. hu/2016NY/Gyulai_Szolnoki_Kenez_Peto_E16NY.pdf (accessed 30.04.2021).

Gyulai F., Szolnoki L., Rosza Z., Merkl M., Peto A. 2017. Plant Based Subsistence Strategy of the Medieval Ishmaelite $\left(12^{\text {th }}-13^{\text {th }}\right.$ c. $)$ Population in the Carpathian Basin (NE-Hungary). Environmental Archaeology 22: 1-19. 
Храбак, Б. 1994. Ратарство северне Србије у последњој трећини XV века. Зборник радова Народног музеја XXII-XXIII: 33-70.

Hrotko, K. Feng, Y. Halasz, J. 2020. Spontaneous hybrids of Prunus fruticosa Pall. in Hungary. Genet Resour Crop Evol 67: 489-502.

Hughes, M., Diaz, H. 1994. Was there a "Medieval Warm Period", and if so, where and when? Climatic Change 26: 109-142.

Јиречек, К. 1978. Историја Срба. Књига друга. Београд: Слово љубве.

Kim, K., Anderson, J.A., Webb, S.L., Newell, M.A., Butler, T.J. 2017. Variation of winter forage production in four small grain species: oat, rye, triticale and wheat. Pak. $J$. Bot., 49(2): 553-559.

Komatina, P. 2012. The Term Bulgaria in the $11^{\text {th }}$ and $12^{\text {th }}$ Centuries and the Territory of the Archbishopric of Ohrid. Byzantine World in the Balkans, Volume II, urednici B. Krsmanović, Lj. Maksimović, R. Radić. Beograd: Vizantološki institut SANU: 41-56.

Kosterin, O., Bogdanova, V., Mglinets, A. 2020. Wild pea (Pisum sativum L. subsp. elatius (Bieb.) Aschers. et Graebn. s.1.) at the periphery of its range: Zagros Mountains. Вавиловский журнал генетики и селекции 24(1): 60-68.

Kroll, H. 1991. Sudosteuropa. Progress in Old World Palaeoethnobotany, editors K. E. Behre, K. Wasylikowa, W. van Zeist. London: Taylor \& Francis: 161-177.

Lagler, R., Gyulai, G., Humphreys, M., Szabo, Z., Horvath, L., Bittsanszky, A., Kiss, J., Holly, L., Heszky, L. 2005. Morphological and molecular analysis of common millet (P. miliaceum) cultivars compared to a DNA sample from the 15th century (Hungary). Euphytica 146(1): 77-85.

Marković, N., Roeter, A., Birk, J. 2019. Bioarheološka istraživanja svakodnevnog života u Caričinom Gradu. Leskovački zbornik LIX: 21-44.

Medović, A. 2008. Gamzigradski ratari - dva koraka napred, jedan korak nazad. Rad Muzeja Vojvodine 50: 151-161.

Medović, A. 2015. Arheobotanički vodič kroz Novi Sad. Novi Sad: Platoneum.

Medović, A. 2016. Colouring wildflowers of arable land in the vicinity of fortress Koznik: new archaeobotanical record from medieval Serbia. Rad Muzeja Vojvodine 58: 7-22.

Mihailović, V., Mikić, A., Vasić, M., Ćupina, B., Đurić, B., Duc, G., Stoddard, F., Hauptvogel, P. 2010. Neglected legume crops of Serbia - Faba bean (Vicia faba). Ratarstvo i povrtarstvo 47 (1): 27-32.

Milatović, D., Nikolić, D. 2011. Oplemenjivanje trešnje i višnje u svetu. Zbornik radova III savetovanja „Inovacije u voćarstvu”, urednik D. Milatović. Beograd: Poljoprivredni fakultet, Katedra za voćarstvo: 21-47.

Милићевић, В. 2010. Клима средњовековне Србије: покушај реконструкције на бази астрономских елемената и шумског фонда. Зборник радова конференције "Развој астрономије код Срба VI”, уредник М. Димитријевић. Београд, 22-26. април 2010: Астрономска опсерваторија Београд и Астрономско друштво „Руђер Бошковић”: 659-678.

Mrvić, V., Kostić-Kravljanac, Lj., Čakmak, D., Sikirić, B., Brebanović, B., Perović, V., Nikolovski, M. 2011. Pedogeochemical mapping and background limit of trace elements in soils of Branicevo Province (Serbia). Journal of Geochemical Exploration 109: 18-25. 
Новаковић, С. 1904. Примери књижевности и језика старога и српско-словенскога. Београд: Државна штампарија.

Ozanić Roguljić, I. 2015. Interpretation of archaeobotanical and archaeozoological findings from Roman context according to historical sources. Roman village in the province of Upper Pannonia: Virovitica Kiskorija South. Zagreb: Institut za arheologiju: 327-334. Pliny the Elder. Natural History. I-X volume.

Поповић М., Иванишевић В. 1988. Град Браничево у средњем веку. Старинар 39: 125-179.

Popović, D., Marjanović-Dušanić, S., Popović, M. 2016. Daily life in medieval Serbia. Beograd: Clio.

Rapan Papeša, A., Kenez, A., Peto, A. 2015. The Archaeobotanical Assesment of Grave Samples from the Avar Age Cemetery of Nustar (Eastern Croatia). Pril. Inst. Arheol. Zagrebu 32: 261-288.

Спасић-Ђурић, Д. 2015. Град Виминачијум. Пожаревац: Народни музеј Пожаревац. Спасић-Ђурић, Д. 2016. Белешка о новим истраживањима византијског Браничева. Византијско наслеђе и српска уметност I-III, уредници Д. Поповић и Д. Војводић. Београд: Српски комитет за византологију, Службени гласник, Византолошки институт САНУ: 109-115.

Spasić-Đurić, D., Jovanović, S. 2018. A 12th century set of marvered purple glass vessels from Braničevo (Serbia). Cтаринар LXVIII: 151-173.

Stojaković, M. 1987. Braničevski tefter - poimenični popis pokrajine Braničevo iz 1467. godine. Beograd: Istorijski institut SANU.

Šoštarić, R. 2004. Archaeobotanical analysis of findings from Torcec-Gradic archaeological site. Podravina 3 (6): 107-115.

Šoštarić, R. 2015. Biljni ostaci iz antičkog i srednjevjekovnog naselja na lokalitetu Virovitica Kiškorija Jug . Rimsko selo u provinciji Gornjoj Panoniji: Virovitica Kiškorija Jug. Zagreb: Institut za arheologiju: 311-326.

Šoštarić, R., Šegota, V. 2010a. Analiza biljnih ostataka iz srednjovjekovnog burga Vrbovca u Klenovcu Humskome. Burg Vrbovec u Klenovcu Humskome: deset sezona arheoloških istraživanja. Zagreb: Muzeji Hrvatskog Zagorja \& Institut za arheologiju: 247-253.

Šoštarić R., Šegota V. 2010b. Analiza biljnih ostataka sa srednjevjekovnog lokaliteta Torčec kraj Koprivnice. Podravina u ranom srednjem vijeku: rezultati arheoloških istraživanja ranosrednjovjekovnih nalazišta u Torčecu. Zagreb: Institut za arheologiju: 373-388.

Treasure, E., Church, M. 2017. Can’t find a pulse? Celtic bean (Vicia faba L.) in British prehistory. Environmental Archaeology, 22(2): 113-127.

Valamoti, S., Moniaki, A., Karathanou, A. 2011. An investigation of processing and consumption of pulses among prehistoric societies: archaeobotanical, experimental and ethnographic evidence from Greece. Vegetation History and Archaeobotany 20, 381-396. Vasić, M., Mihailović, V., Mikić, A., Gvozdanović-Varga, J. 2006. Faba bean - past, present and future. Conference: IV međunarodne eko-konferencije Zdravstveno bezbedna hrana, 20-23 septembar. Novi Sad: Ekološki pokret grada Novog Sada. 
Византијски извори IV. 2007. Византијски извори за историју народа Југославије I-VI, Београд 1955-1986, ed. Љ. Максимовић, Византолошки институт Српске Академије наука и уметности, Посебна издања 35 , Београд.

Wojcicki, J., Marhold, K. 1993. Variability, hybridization and distribution of Prunus fruticosa (Rosaceae) in the Czech Republic and Slovakia. Polish Bot. Stud. 5: 9-24.

Yang, Y., Tian, M., Liu, X., Li, Y., Sun, Z. 2020. Complete chloroplast genome of Prunus fruticosa and its implications for the phylogenetic position within Prunus sensulato (Rosaceae). Mitohondrial DNA 5(3): 3606-3608.

Zeven, A.C. 1997. The introduction of the common bean (Phaseolus vulgaris L.) into Western Europe and the phenotypic variation of dry beans collected in the Netherlands in 1946. Euphytica 94: 319-328.

Zohary, D., Hopf, M. 2000. Domestication of plants in the Old World. New York: Oxford University Press. 
Ана Смук

Нови Сад

\section{АРХЕОБОТАНИЧКИ ОСТАЦИ СА СРЕДЊОВЕКОВНОГ ЛОКАЛИТЕТА БРАНИЧЕВО (СРБИЈА)}

Кључне речи: археоботаника, средњи век, биљни остаци, боб (Vicia faba), степска вишња (Prunus fruticosa), Браничево

Истраживања локалитета Мали Град - Тодића црква, започета 2007. године, изнедрила су прве налазе биљних остатака са средњовековног Браничева. У оквиру куће 4, објекта који је налазима новца Јована II Комнина (1118-1143) и Манојла I Комнина (1118-1180) смештен у 12. век, пронађен је велики број керамичких посуда и уломака керамике који су затворени слојем пожара. Поред једне посуде, лонца (сл. 3) који је лежао у фрагментима у северозападном делу куће пронађено је 333 налаза боба (Vicia faba), 2 зрна грашка (Pisum elatius), и 2 семена која вероватно припадају јечму (cf. Hordeum vulgare). Сам контекст налаза указује на складиштење боба (сл. 6), који се вероватно налазио на нешто вишој полици, судећи према посуди која је видно изломљена и налазима расутим око ње, за разлику од других посуда, које су, иако попуцале под утицајем ватре, остале сачуване in situ (Спасић-Ђурић 2016, 112). У близини овог налаза се наишло на још три семена, од којих једно припада ражи (Secale cereale), док друга два вероватно припадају просу (cf. Panicum miliaceum).

У југоисточном делу куће 4 пронађена је глеђосана керамичка посуда (сл. 4), у којој је пронађен још један налаз 37 биљних остатака, у овом случају степске вишње (Prunus fruticosa), што представља први налаз ове врсте (сл. 7) у средњовековном контексту Балкана. За разлику од махунарки и житарица пронађених у потпуно угљенисаном стању, степска вишња је била напола угљенисана. Највероватније је била већ осушена у тренутку када је дошло до пожара, што би објаснило очуваност самог плода, односно „меса” воћке. Очуваност плода, с друге стране, отежало је саму идентификацију на нивоу врсте јер се „месо” залепило за коштицу те је било немогуће истражити спољашњу површину коштице вишње. На основу упоређивања са више врста унутар рода Prunus, унутрашњег пресека коштице, њених димензија и облика, дошло се до закључка да се ради о налазу степске вишње. Степска вишња је домаћа врста и може се срести широм Балканског полуострва 
(Burger et al. 2011, 2; Yang et al. 2020, 3606). Отпорна је на зиму и сушу, раније сазрева, а често се може срести при обалама реке, у клисурама, равницама са степском вегетацијом и на брдима (Wojcicki, Marhold 1993, 15; Hrotko et al. 2020, 489-490). Укус ове биљке је слатко-киселкаст, понекад може бити и опор; када се ради о могућностима њене употребе, контекст налаза упућује могуће на коришћење при справљању напитака, или директну конзумацију сасушеног плода. Сама биљка користи се још и за справљање колача, џемова, пекмеза, компота, меда или у медицинске сврхе за сузбијање кашља, ублажавање прехладе и слично (Dzhangaliev et al. 2003, 327; Barać 2016, 4).

Налази житарица са Браничева уклапају се у слику коју нам дају историјски извори као и археоботанички налази са истовремених локалитета на подручју Србије (Боројевић 2002; Borojević 2005; Filipović, Bikić 2015; Medović 2016). Примерци ражи, јечма и проса представљају уобичајен налаз на средњовековном репертоару ових простора, који опстаје и током турског периода, као што се може видети у дефтерима из 1476. године (Stojaković $1987,81-2)$. Налази боба указују нам на значај махунарки у исхрани становништва на Браничеву, као и о навикама презервирања и складиштења за будућу употребу. Археолошки (Спасић-Ђурић 2016) и биоархеолошки налази куће 4 указују на живу динамику и добру организацију, као и економију која се није базирала само на основним животним намирницама, већ се давало значаја и намирницама које су имале своје предности у ширем контексту употребе. 